\title{
KERAGAAN PRODUKSI BUDIDAYA IKAN MAS DI KJA WADUK Ir. H. DJUANDA, JATILUHUR
}

\author{
Estu Nugroho \\ Pusat Penelitian dan Pengembangan Perikanan Budidaya \\ Jl. Ragunan 20, Pasar Minggu, Jakarta Selatan 12540 \\ E-mail: engroho@yahoo.com
}

\begin{abstract}
ABSTRAK
Sistem budidaya ikan mas di Kantong Jaring Apung (KJA) merupakan salah satu teknologi budidaya yang paling efisien sampai saat ini. Salah satu sentra produksi ikan mas sistem KJA adalah di KJA Waduk Ir. H. Djuanda, Jatiluhur. Perkembangan budidaya ikan mas di KJA Jatiluhur perlu diketahui sebagai bahan evaluasi untuk menjaga keberlangsungan budidaya ikan mas di KJA dan pengembangannya sebagai salah satu usaha bisnis yang menguntungkan Secara rata-rata budidaya mas di KJA Jatiluhur mempunyai nilai sintasan = $85,19 \%$ efisiensi pakan $(E P)=57,15 \%$ pertambahan biomassa $=13,05 \mathrm{~kg} /$ hari $/$ unit; dan harga pokok produksi (HPP) $=$ Rp 11.254,-/kg.
\end{abstract}

KATAKUNCl: produksi, ikan mas, KJA Jatiluhur

\section{PENDAHULUAN}

Budidaya ikan mas di Kantong Jaring Apung (KJA), khususnya di Jawa Barat, telah dimulai sejak awal pemanfaatan waduk atau bendungan buatan dimulai, yaitu Waduk Saguling, Waduk Cirata, dan Waduk Ir. H. Djuanda yang lebih dikenal dengan Jatiluhur pada tahun 1980-an. Perkembangan budidaya ini sempat mengalami masa keemasan pada awal pemanfaatan waduk, di mana kualitas airnya masih sangat layak, antara lain kandungan oksigen yang cukup tinggi (> $3 \mathrm{mg} / \mathrm{L}$ ), kandungan amoniak yang relatif rendah $(<0,1 \mathrm{mg} / \mathrm{L})$, serta kecerahan yang masih di atas $30 \mathrm{~cm}$.

Berkaitan dengan tingkat polusi yang sudah sangat tinggi, khususnya di Waduk Saguling dan Cirata, serta adanya wabah yang disebabkan oleh virus herpes (Koi Herpes Virus, KHV), dewasa ini budidaya ikan mas di Waduk Saguling sudah dapat dikatakan tidak ada lagi (Dinas Perikanan dan Kelautan Provinsi Jawa Barat, 2010), sedangkan di Waduk Cirata sudah mulai menurun (tercatat produksi ikan mas dari tahun 2005 sebesar 18.497 ton menjadi 18.482 ton di tahun 2009 . Keadaan yang masih cukup baik terjaga adalah budidaya ikan mas di Waduk Jatiluhur, di mana produksinya pada tahun 2005 tercatat sebesar 30.180 ton dan pada tahun 2009 menjadi 39.565 ton (Dinas Perikanan dan Kelautan Provinsi Jawa Barat, 2010).

Dewasa ini tercatat hampir sekitar 4.000 ton pakan dibutuhkan untuk budidaya ikan di Waduk Jatiluhur. jika produksi ikan mas adalah setengah dari jumlah pakan yang digunakan maka produk ikan mas yang dikeluarkan dari KJA Jatiluhur mencapai sekitar 2.000 ton untuk setiap bulannya, dan jika dinilai dalam rupiah merupakan jumlah yang cukup besar (Rp 25 milyar dengan harga ikan mas saat ini Rp 12.500,-/kg) belum termasuk nilai hasil perbenihannya dan industri pakan (Komunikasi Pribadi dengan Distributor Pakan).

Kenyataan ini semakin memperkuat keyakinan kita bahwa agribisnis ikan mas merupakan suatu kegiatan yang menjanjikan keuntungan. Namun demikian, penanganan yang profesional dalam menjalankan sistem bisnis ini juga diperlukan untuk menjamin kelangsungan hidup atau kelanggengan usaha agribisnis ikan air tawar ini.

Kajian ini merupakan hasil observasi kegiatan budidaya ikan mas di KJA Jatiluhur selama tahun 2011 untuk memberikan informasi tentang keragaan produksi ikan mas serta nilai ekonomisnya sebagai kegiatan agribisnis bidang perikanan.

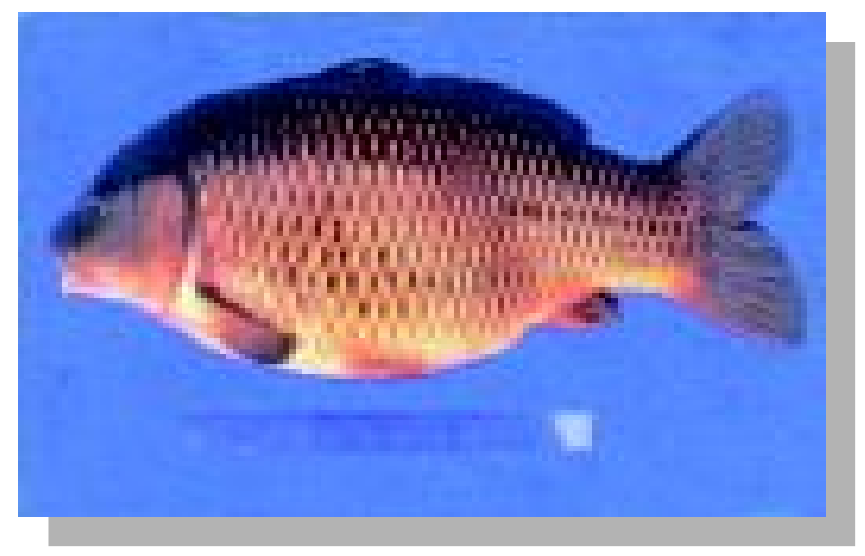

Gambar 1. Ikan mas varietas Rajadanu (Foto: BRPBAT, 2011) 


\section{Sistem Budidaya KJA "KOLOR"}

Budidaya ikan mas umumnya dilakukan bersama dengan ikan nila di bagian bawah jaringnya yang dikenal dengan sistem "kolor'. Sistem kolor berupa jaring ganda di mana jaring atas digunakan untuk pemeliharaan ikan mas sedangkan jaring bawah untuk pemeliharaan ikan nila. Sistem ini dikembangkan secara tidak sengaja oleh para pembudidaya di Cirata dalam rangka efisiensi pakan ikan mas, yang kemudian diadopsi secara luas oleh para pembudidaya ikan KJA di daerah lainnya, termasuk Waduk Jatiluhur.

Ikan mas dipelihara pada jaring ukuran $7 \mathrm{~m} \times 7 \mathrm{~m}$ dengan kedalaman jaring $3 \mathrm{~m}$. Sedangkan ikan nila dipelihara pada jaring "kolor" ukuran 15 m x 15 m dengan kedalaman jaring $5 \mathrm{~m}$. Pada umumnya yang dimaksud dengan "kolor" adalah empat jaring ikan mas di atas ditampung dalam satu jaring untuk ikan nila pada bagian bawahnya. Jika tidak semua (keempat) jaring ikan mas dimanfaatkan maka disebut sebagai sistem "dok-los". Pemberian pakan hanya dimaksudkan untuk ikan mas, sedangkan ikan nila dianggap tidak diberi pakan.

Pemeliharaan ikan mas di KJA umumnya dilakukan selama 3-4 bulan tergantung ukuran benih saat tebar dan ukuran panen yang diinginkan. Ukuran benih berkisar antara 5-20 g/ekor dengan ukuran panen antar 6-10 ekor/ $\mathrm{kg}$. Pakan yang diberikan adalah pelet tenggelam dengan kadar protein antara $24 \% 26 \%$

Pada sistem budidaya KJA ini, biaya pakan semua dibebankan pada budidaya ikan mas, sedangkan budidaya ikan nila dianggap tidak diberi pakan. Sehingga keberhasilan budidaya ini sangat tergantung pada hasil produksi ikan mas. Jika hasil produksi ikan mas baik maka keuntungan sistem budidaya ini sangat tinggi, mengingat hasil budidaya ikan nila selalu untung, sebaliknya jika produksi budidaya ikan mas merugi maka berarti akan mengurangi keuntungan dari hasil budidaya ikan nila. Sebagai contoh, jika budidaya ikan mas mempunyai efisiensi pakan mencapai 50\%60\%maka budidaya ikan mas akan dapat menghasilkan keuntungan sekitar Rp 1-2 juta dalam satu jaring sedangkan keuntungan ikan nila yang dipelihara di bawahnya mencapai Rp 2-3 juta sehingga total keuntungan yang didapat adalah Rp 3-5 juta. Sebaliknya jika efisiensi pakan budidaya ikan mas hanya di bawah 40\%50\%kemungkinan budidaya ikan mas akan balik modal sehingga keuntungan hanya didapatkan dari budidaya ikan nila yaitu sebesar 2-3 juta rupiah saja.

\section{Keragaan Produksi Budidaya KJA Ikan Mas}

Keberagaman kualitas benih yang tersebar di masyarakat untuk dapat dimanfaatkan oleh para pembudidaya ikan mas di KJA membuat hasil yang diperoleh juga sangat bervariasi. Sampai saat ini belum ada jaminan kepastian pasokan benih, baik jumlah maupun ukurannya, sehingga hanya berdasarkan adanya benih mereka berbudidaya.

Dari serangkaian uji coba terapan tingkat lapangan (dilakukan oleh Tim Cianjur) diperoleh hasil yang cukup komprehensif seperti yang tertera pada Tabel 1 .

Terlihat bahwa ukuran benih yang digunakan pada KJA Jatiluhur berkisar antara 5 hingga 20-21 g, dengan tingkat kepadatan mulai 33 hingga 114 ekor $/ \mathrm{m}^{3}$. Dengan lama pemeliharaan ikan mas di KJA Jatiluhur berkisar antara 89-95 hari, didapatkan pertambahan biomassa ratarata $13,05 \mathrm{~g}$; di mana pertambahan biomassa terbesar yaitu 17,6 kg/hari (ukuran benih $5 \mathrm{~g}$ ) dan terkecil 11,3 g (ukuran benih $>20 \mathrm{~g}$ ). Sintasan rata-rata yang tercatat adalah $85,19 \%$ dengan nilai terbesar pada benih ukuran $>20$, dan nilai terkecil pada benih dengan ukuran $5 \mathrm{~g}$. Sedangkan efisiensi pakan bervariasi dengan nilai ratarata adalah 57,15\% nilai tertinggi pada benih ukuran $5 \mathrm{~g}$ $(60,45 \%$, dan terendah pada benih ukuran $11 \mathrm{~g}(54,36 \%)$.

Selanjutnya ditinjau dari aspek ekonomis, harga pokok produksi (HPP) terendah diperoleh dari hasil produksi yang menggunakan benih dengan ukuran $5 \mathrm{~g}$

Tabel 1. Keragaan produksi dan harga pokok produksi budidaya ikan mas di KJA Jatiluhur

\begin{tabular}{ccccccc}
\hline $\begin{array}{c}\text { Ukuran } \\
\text { benih (g) }\end{array}$ & $\begin{array}{c}\text { Kepadatan } \\
\left.\text { (ekor/m } \mathbf{3}^{\mathbf{3}}\right)\end{array}$ & $\begin{array}{c}\text { Waktu } \\
\text { pemeliharaan } \\
\text { (hari) }\end{array}$ & $\begin{array}{c}\text { Biomassa } \\
\text { (kg/unit/hari) }\end{array}$ & $\begin{array}{c}\text { Sintasan } \\
\mathbf{( \% )}\end{array}$ & $\begin{array}{c}\text { Efisiensi } \\
\text { pakan } \\
\mathbf{( \% )}\end{array}$ & $\begin{array}{c}\text { HPP } \\
\mathbf{( R p / k g})\end{array}$ \\
\hline 5 & 114 & 95 & 17,6 & 81,76 & 60,45 & 10.290 \\
8 & 61 & 93 & 11,7 & 81,95 & 56,38 & 11.328 \\
11 & 61 & 89 & 11,6 & 82,67 & 52,36 & 12.244 \\
$>20$ & 33 & 90 & 11,3 & 94,38 & 59,39 & 11.155 \\
\hline & Rataan & & 13,05 & 85,19 & 57,145 & 11.254 \\
\hline
\end{tabular}

Sumber: Perdana (2011) 
(Rp 10.290,-/kg) dan produksi dengan HPP tertinggi terdapat pada KJA dengan menggunakan benih ukuran $11 \mathrm{~g}$ yaitu $\mathrm{Rp} 12.244,-/ \mathrm{kg}$. Secara rata-rata produksi ikan mas dengan menggunakan benih dengan berbagai ukuran memerlukan biaya sebesar Rp 11.254,-/kg. Dengan kata lain, produksi budidaya ikan mas akan tetap langgeng dengan syarat harga ikan mas pada tingkat produsen harus $>\mathrm{Rp} \mathrm{11.254,-//kg}$ (idealnya adalah Rp 14-15 ribu/kg).

\section{Prospek Mendatang Budidaya Ikan Mas di KJAJatiluhur}

Seperti yang telah dijabarkan sebelumnya, budidaya ikan mas di KJA Jatiluhur akan dapat terus bertahan jika harga jual yang ada di tingkat produsen minimal sekitar Rp 11.500,-/kg (Tabel 1). Keberlangsungan ini juga ditunjang dari hasil budidaya ikan nila sebagai ikutannya, di mana tercatat bahwa budidaya ikan nila dengan kepadatan 20-30 ekor $/ \mathrm{m}^{2}$ menghasilkan produksi yang terbaik (Nugroho, 2011).

Upaya lain yang perlu dilakukan adalah dengan memperbaiki teknologi budidaya termasuk dengan penggunaan benih unggul, baik pertumbuhannya maupun yang tahan terhadap serangan virus KHV. Penggunaan benih unggul pada budidaya KJA telah berhasil menaikkan produksi ikan nila 2-3 kali lipat produksi dengan menggunakan benih lokal (Nugroho, 2012). Namun demikian sampai saat ini produksi benih unggul ikan mas masih dalam taraf konstruksi atau pengujian skala laboratorium. Hasil sementara terdapat indikasi bahwa ikan mas varietas Rajadanu dan Majalaya mempunyai hasil yang cukup baik.

Penerapan penggunaan pakan yang diperkaya dengan vitamin C sebagai bahan untuk memperkuat daya tahan terhadap serangan penyakit juga merupakan salah satu upaya untuk menjamin kelangsungan usaha budidaya KJA. Aplikasi vaksin KHV yang ada juga merupakan langkah-langkah yang patut dipertimbangkan mengingat kegiatan ini dapat meningkatkan sintasan hingga $60 \%$ dibandingkan benih ikan mas umumnya. Namun faktor ekonomis merupakan salah satu kendala pada saat ini di mana harga vaksin yang beredar dapat membebani ongkos produksi (diperkirakan benih menjadi Rp 60-70 ribu/kg).

Pengembangan teknologi pasca panen ikan mas merupakan upaya lainnya yang dapat mempengaruhi keberlangsungan usaha budidaya ikan mas di KJA. Dengan adanya diversifikasi pemanfaatan produk ikan mas hasil budidaya maka diharapkan harga jual ikan mas di tingkat produsen dapat didongkrak sehingga marjin yang ada semakin lebih luas dan para pembudidaya menjadi lebih dapat memetik keuntungan yang sangat wajar dengan kondisi yang ada.

Jika upaya-upaya tersebut dilakukan dengan baik maka prospek budidaya ikan mas sebagai salah satu unit agribisnis ikan air tawar akan semakin baik mengingat kebutuhan pasar yang ada di Jawa Barat yang saat ini hampir sebagian besar dipasok dari produksi Jatiluhur akan dapat menyerap produksi Jatiluhur dan keuntungan yang lebih besar daripada saat ini.

\section{PENUTUP}

Budidaya ikan mas di KJA Ir. H. Djuanda, Jatiluhur masih dapat diandalkan sebagai usaha yang menguntungkan dengan tingkat HPP Rp 11.500,-/kg.

\section{DAFTAR ACUAN}

Dinas Perikanan dan Kelautan Provinsi Jawa Barat. 2010. Buku statistik perikanan budidaya tahun 2009. Dinas Perikanan dan Kelautan Provinsi Jawa Barat. Bandung.

Nugroho, E. 2011. Kajian lapang budidaya KJA ikan nila "mandiri" di Waduk Cirata dan Jatiluhur (antara kenyataan dan harapan). M edia Akuakultur, 6(1): 54-58.

Nugroho, E. 2012. Mendongkrak keuntungan KJA Jatiluhur dengan menggunakan "nila unggul". Trobos Edisi 150, Tahun XIII, Maret 2012. 